\title{
News and Events
}

Inaugural Meeting: European Historic Towns Forum

1-3 October 1998, Malta

Information: Chris Winter

Tel: +44 117975 0459. Fax: +44 1179750460 .

Second International Seminar and the Fourth International Meeting

5-10 October 1998, Conservation and urban sustainable development: a theoretical framework, Federal University of Pernambuco, Recife, Brazil. Information: Dr. Silvio M Zancheti, CECI, R. do Bom Jesus, 227, 4 andar, 50741 539, Recife, Brazil. Tel: +55 81224 5060. Fax: +55 812245662 .

Email: ceci@npd.ufpe.br

UDG Annual Conference

16-17 October 1998, Title: TBA, Oxford Brookes University, Oxford, UK

Information: UDG Office, 6 Ashbrook Courtyard, Westbrook Street, Blewbury, OXON, OX11 9QH

Tel: +44 (0) 1235851 415. Fax: +44 (0) 1235851 410.

\section{Seventh International Conference}

26-27 November 1998, Application/Implication of computer networking in Architecture, Construction, Design, Civil Engineering \& Urban Planning: CYPERDESIGN: Media, Communication and Design Practice

Information: Delia Atherton, University of Paisley, Scotland

Tel: +44 41848 3300. Fax: +44 418483542 .

EHTF AGM and Annual Conference

November 1998, Living in the Centre, Brighton, UK

Information: Chris Winter, Business Manager,
EHTF PO Box 22, Bristol BS16 1RZ

Tel: +44 (0) 117975 0459. Fax: +44 (0) 117975 0460.

Fourth European Digital Cities Conference November 1998, Changing patterns of urban life, Salzburg, Austria Information: EDC Coordination Office, c/o Eurocities, 18 Square de Mees, B-1050 Brussels.

Tel: +32 2552 0868. Fax: +32 25520889 .

Email: telecities@mrcl.poptel.org.uk

Conference: Cities at the Millenium

December 1998, RIBA hosted by University of East London, UK

Call for papers conference deadline: 15 June 1998 Papers will be offered on the following themes: Imagining cities, The Economy and the city, Cities of difference and division, Public cultures and everyday space, urban politics and urban intervention, London at the Millenium.

Email: s.watson@uel.ac.uk or gary.bridge@bristol. ac.uk

Sixth IASTE (International Association for the Study of Traditional Environments) Conference 15-29 December 1998, Manufacturing Heritage, Consuming Tradition: development, Preservation and Tourism in the Age of Globalisation, Cairo, Egypt.

Information: IASTE 98 Conference, Centre for Environmental Design Research, 390 Wurster Hall, University of California, Berkeley, CA 94720-1839, USA.

Tel: +1 510642 2896. Fax: +1 5106435571 .

Email: iaste@ced.berkeley.edu

Second International Symposium

29 March-2 April 1999, Space Syntax, Brazil

Tel: +55 61273 1254. Fax: +55 619881724 .

Email: fredhol@guarany.cpd.unb.br 